\title{
Review
}

\section{The Female Reproductive Tract Microbiome-Implications for Gynecologic Cancers and Personalized Medicine}

\author{
Anthony E. Rizzo ${ }^{1,+}$, Jennifer C. Gordon ${ }^{1,+}{ }^{+}$, Alicia R. Berard ${ }^{2,3}(\mathbb{D}$, Adam D. Burgener $2,3,4,5, *$ \\ and Stefanie Avril 4,5,* \\ 1 Department of Obstetrics and Gynecology, Division of Gynecologic Oncology, University Hospitals \\ Cleveland Medical Center and Case Western Reserve University, Cleveland, OH 44106, USA; \\ Anthony.Rizzo2@UHhospitals.org (A.E.R.); Jennifer.Gordon@UHhospitals.org (J.C.G.) \\ 2 Department of Obstetrics and Gynecology, University of Manitoba, Winnipeg, MB R3E 0W2, Canada; \\ alicia.berard@case.edu \\ 3 Center for Global Health and Diseases, Case Western Reserve University, Cleveland, OH 44106, USA \\ 4 Case Comprehensive Cancer Center, Cleveland, OH 44106, USA \\ 5 Department of Pathology, Case Western Reserve University and University Hospitals Cleveland Medical \\ Center, Cleveland, OH 44106, USA \\ * Correspondence: adam.burgener@case.edu (A.D.B.); stefanie.avril@case.edu (S.A.) \\ + These authors contributed equally.
}

Citation: Rizzo, A.E.; Gordon, J.C.; Berard, A.R.; Burgener, A.D.; Avril, S. The Female Reproductive Tract Microbiome-Implications for Gynecologic Cancers and Personalized Medicine. J. Pers. Med. 2021, 11, 546. https://doi.org/ 10.3390/jpm11060546

Academic Editor: Eleanor E. R. Harris

Received: 6 April 2021

Accepted: 5 June 2021

Published: 11 June 2021

Publisher's Note: MDPI stays neutral with regard to jurisdictional claims in published maps and institutional affiliations.

Copyright: (c) 2021 by the authors. Licensee MDPI, Basel, Switzerland. This article is an open access article distributed under the terms and conditions of the Creative Commons Attribution (CC BY) license (https:/ / creativecommons.org/licenses/by/ $4.0 /)$.
Abstract: The microbial colonization of the lower female reproductive tract has been extensively studied over the past few decades. In contrast, the upper female reproductive tract including the uterine cavity and peritoneum where the ovaries and fallopian tubes reside were traditionally assumed to be sterile under non-pathologic conditions. However, recent studies applying nextgeneration sequencing of the bacterial $16 \mathrm{~S}$ ribosomal RNA gene have provided convincing evidence for the existence of an upper female reproductive tract microbiome. While the vaginal microbiome and its importance for reproductive health outcomes has been extensively studied, the microbiome of the upper female reproductive tract and its relevance for gynecologic cancers has been less studied and will be the focus of this article. This targeted review summarizes the pertinent literature on the female reproductive tract microbiome in gynecologic malignancies and its anticipated role in future research and clinical applications in personalized medicine.

Keywords: female reproductive tract microbiome; upper reproductive tract microbiome; vaginal microbiome; uterine microbiome; gynecologic cancer; endometrial cancer; ovarian cancer

\section{Introduction}

The human microbiome refers to the collective genomes of bacteria, viruses, bacteriophages, protozoa, and fungi that symbiotically inhabit the human body. While microorganisms make up only about 1 to 3 percent of the human body mass, microbial cells outnumber human cells by an estimated factor of ten [1]. The Human Microbiome Project, a conceptual extension of the Human Genome Project [1,2], has been increasing the understanding of the microbiome's dynamic role in influencing inflammation, metabolic and cellular pathways, mucosal homeostasis, and host immune responses throughout the human body [3] as well as its perturbation in multiple types of human diseases including neoplastic processes. The gut microbiome has been implicated in cancer progression and immunotherapeutic responsiveness of different cancers [4,5], and emerging evidence suggests that the female reproductive tract microbiome may play a similar role, particularly in gynecologic malignancies. Cancers of the female reproductive tract account for more than 100,000 new cancer diagnoses and up to 30,000 deaths per year in the United States [6-9]. Gynecologic malignancies in which microbiomes are currently under study encompass cancers of the lower female reproductive tract, particularly the uterine cervix, as well as the ovary and endometrium in the upper female reproductive tract. 
Recent studies applying next-generation sequencing of the bacterial $16 \mathrm{~S}$ ribosomal RNA (16S rRNA) gene have provided convincing evidence for the existence of an upper female reproductive tract microbiome. Over the past few years, studies of endometrial and peritoneal samples obtained from healthy women and those with benign and noninfectious gynecologic conditions suggest a microbiota continuum with decreasing biomass and increasing diversity from the lower to upper female reproductive tract $[10,11]$. Data on upper female reproductive tract microbiome composition and its association with gynecologic cancers can be considered preliminary at present. Further studies including multi-omics and systems biology approaches are required to determine functional relevance rather than pure presence of different microbiota and to establish causative relationships with gynecologic diseases including cancer.

\section{The Lower Female Reproductive Tract (FRT) and Vaginal Microbiome}

The mucosal layer of the lower female reproductive tract (FRT) contains commensal bacteria that play important roles for mucosal health. The vaginal microbiome is commonly composed of different species of Lactobacillus, which can include L. crispatus, L. gasseri, L. iners, L. jensenii, and others [12]. A Lactobacillus-dominant vaginal microbiome is considered to be favorable due to the protective characteristics that are provided by these bacterial communities. This includes the production of lactic acid to lower the vaginal $\mathrm{pH}$ and the production of bacteriocins and hydrogen peroxide providing an acidic and antimicrobial environment unfavorable for invading pathogens [13,14]. Nevertheless, different Lactobacillus species vary considerably in their ability to produce lactic acid and antimicrobial factors, and several are associated with increased mucosal inflammation [15,16]. Molecular profiling has increased the understanding of vaginal microbial diversity, which has been classified into so-called community-state types as defined by the predominant taxa [12]. Often, Lactobacillus is not the dominant microorganism, and many women have higher diversity non-Lactobacillus microbiota characterized by an overgrowth of obligate and facultative anaerobes such as Gardnerella, Prevotella, Atopobium, and Mobiluncus, which is known as microbial dysbiosis or bacterial vaginosis. Vaginal microbial dysbiosis is associated with changes to the mucosal microenvironment, including increased pro-inflammatory cytokines [17], increased numbers of immune cells such as CD4+ T-cells $[13,18]$ that are activated, altered immune pathways [18-21], epithelial barrier disruption [22], and production of immunomodulatory metabolites $[23,24]$. Vaginal microbial dysbiosis is associated with numerous adverse reproductive health outcomes, including increased acquisition of sexually transmitted infections, increased risk of pre-term birth, and increased risk of HPV infection and subsequent cervical cancer, among others [25-30]. Bacterial vaginosis is the most common vaginal condition for women of reproductive age [31], affecting $23-29 \%$ of women globally [32] and causing detrimental effects on a woman's quality of life physically, emotionally, sexually, and socially [33]. The association between highly polymicrobial non-Lactobacillus dominant vaginal microbiome profiles with increased risk of HPV infection, persistence, delayed clearance, and increased risk of developing HPV-associated cervical neoplasia was demonstrated in multiple studies [28-30] and was recently reviewed elsewhere [34].

\section{The Upper Female Reproductive Tract (FRT) Microbiome and Gynecologic Cancers}

Studying the upper FRT and specifically the intrauterine and endometrial microbiome is hampered by challenges of sterile access without cervicovaginal contamination and the significantly lower biomass of the upper compared to the lower FRT. These challenges in studying upper FRT microbiota and variability in reported microbiome composition were also discussed in a prior review article and commentary [35-37]. A limited number of recent studies, summarized in Table 1, have analyzed the presence and composition of a possible uterine and upper FRT microbiome using either transcervical access to the uterine cavity, or sterile access following sterile transection of surgical hysterectomy specimens or during elective caesarean section. Transcervical endometrial specimens included sampling 
of catheter-tips following embryo transfer for in vitro fertilization (IVF) [38,39], aspiration of endometrial fluid [40], endometrial swabs [41-43], or transcervical tissue sampling by endometrial biopsy or curettage $[41,44,45]$. Approaches attempting sterile endometrial sampling to avoid passage of the endocervix used sterilely opened hysterectomy specimens from women with benign uterine disease or endometrial cancer to collect endometrial swabs $[10,11,46]$ sometimes with concurrent endometrial tissue samples [47-50] or endometrial tissue samples obtained at the time of elective caesarean section [51] (see Table 1).

Published reports to date suggest that the upper FRT shares some bacterial species with the lower FRT, which may act as a reservoir for both healthy commensal or pathogenic populations [11,50]. Additional possible routes of transmission and microbial seeding of the uterine cavity include hematogenous spread of gut and oral microbiota; oral and perianal mucosa of an individual and their sexual partners; and microbiota in semen [35,52-56].

Although the vaginal microbiome is dominated by Lactobacillus species in the majority of women, it is unclear if this characteristic is shared in healthy or disease states of the upper FRT including the endocervical canal and uterine cavity. While most studies of transcervically obtained intrauterine samples found a dominance of Lactobacillus [38-42,44,45], the presence and relative abundance of Lactobacillus in uterine samples was more variable when obtained from sterilely opened hysterectomy specimens $[10,11,46-50]$. Several studies that compared lower and upper FRT microbiomes from the same individual and endometrial samples which were not collected transcervically have suggested decreasing abundance of Lactobacillus from the lower to upper FRT microbiomes. These studies found greater diversity in the uterine cavity and greater abundance of species other than Lactobacillus both in states of health and malignancy $[11,44,46,48]$. Despite some compositional overlap between lower and upper FRT, functional analyses of the upper FRT microbiome have not yet been reported, and it is unknown whether the same bacterial species may have distinct interactions with the mucosa of the endometrium compared to the vagina or cervix.

The immunological environment of the endometrium and its ability to respond to various pathogens and to modulate immune responses has been demonstrated in the context of embryo implantation, infertility treatments, and reproductive health outcomes $[57,58]$. The importance of host immune responses within the endometrium has long been recognized for immune tolerance to fetal antigens and to allow trophoblast invasion and vascular remodeling during implantation. In addition, there is an emerging notion that host immune responses in the endometrium may be further modulated by the existence of an upper FRT and uterine microbiome $[57,58]$. Future studies investigating the functional relationship between the microbiome, mucosal inflammation, and host immune responses within the upper FRT and uterine cavity in the context of pregnancy and gynecologic cancers may inform each other and ultimately lead to personalized interventions. 
Table 1. Summary of studies analyzing the upper FRT microbiome, including uterine cavity and endometrium, ovaries, fallopian tubes, and peritoneal cavity.

\begin{tabular}{|c|c|c|c|c|c|c|}
\hline $\begin{array}{l}\text { Year and } \\
\text { First Author }\end{array}$ & Study Subjects & Study Region & Microbial Analysis & Sampling Method & $\begin{array}{l}\text { Dominant Uterine } \\
\text { Bacterial Organisms }\end{array}$ & Main Findings \\
\hline $\begin{array}{l}2015 \\
\text { Mitchell [10] }\end{array}$ & $\begin{array}{l}58 \text { women, mean age } 43 \\
\text { years, undergoing surgery } \\
\text { for benign uterine disease }\end{array}$ & United States & $\begin{array}{l}\text { qPCR for } 12 \\
\text { species-specific } 16 \mathrm{~S} \\
\text { rRNA genes }\end{array}$ & $\begin{array}{l}\text { Sterile collection of uterine } \\
\text { and endocervical swabs at } \\
\text { time of surgery, surgeries } \\
\text { completed without } \\
\text { intracavitary uterine } \\
\text { manipulator }\end{array}$ & $\begin{array}{l}\text { Species: } \\
\text {-Lactobacillus iners (45\%) } \\
\text {-Lactobacillus crispatus (33\%) } \\
\text {-Prevotella spp. }(33 \%)\end{array}$ & $\begin{array}{l}\text { The upper FRT is not sterile. } \\
\text { Upper FRT microbiome is } \\
\text { lower in biomass than is the } \\
\text { lower FRT. }\end{array}$ \\
\hline $\begin{array}{l}2016 \\
\text { Fang [41] }\end{array}$ & $\begin{array}{l}30 \text { reproductive age women } \\
\text { with regular menses with or } \\
\text { without endometrial polyps }\end{array}$ & China & 16S rRNA Seq (V4) & $\begin{array}{l}\text { Transcervical endometrial } \\
\text { swabs and tissue sampling } \\
\text { using cervicovaginal prep } \\
\text { and vaginal sleeve }\end{array}$ & $\begin{array}{l}\text { Genera: } \\
\text {-Lactobacillus }(26 \%) \\
\text {-Enterobacter }(16 \%) \\
\text {-Pseudomonas }(13 \%)\end{array}$ & $\begin{array}{l}\text { The uterine cavity is not } \\
\text { sterile. } \\
\text { Differences in population } \\
\text { may associate with the } \\
\text { presence of endometrial } \\
\text { polyps. }\end{array}$ \\
\hline $\begin{array}{l}2016 \\
\text { Franasiak [38] }\end{array}$ & 33 reproductive age women & United States & 16S rRNA Seq (V2-3) & $\begin{array}{l}\text { Transcervical IVF } \\
\text { catheter-tip sampling }\end{array}$ & $\begin{array}{l}\text { Genera: } \\
\text {-Flavobacterium } \\
\text {-Lactobacillus }\end{array}$ & $\begin{array}{l}\text { Flavobacterium and } \\
\text { Lactobacillus dominate the } \\
\text { uterine cavity microbiome at } \\
\text { time of embryo transfer. }\end{array}$ \\
\hline $\begin{array}{l}2016 \\
\text { Moreno [40] }\end{array}$ & $\begin{array}{l}70 \text { reproductive age women } \\
(3 \text { independent pilot cohorts: } \\
\mathrm{n}=13 \text { and } \mathrm{n}=22 \text { fertile and } \\
\mathrm{n}=35 \text { infertile women) }\end{array}$ & Spain & 16S rRNA Seq (V3-V5) & $\begin{array}{l}\text { Transcervical endometrial } \\
\text { fluid sampling (aspiration of } \\
\text { cervical mucus prior to } \\
\text { endometrial sampling to } \\
\text { reduce contamination) }\end{array}$ & $\begin{array}{l}\text { Genera: } \\
\text {-Lactobacillus }(72 \%) \\
\text {-Gardnerella }(13 \%) \\
\text {-Bifidobacterium }(4 \%) \\
\text {-Streptococcus }(3 \%) \\
\text {-Prevotella }(0.9 \%)\end{array}$ & $\begin{array}{l}\text { The uterine cavity is not } \\
\text { sterile. } \\
\text { Endometrial and vaginal } \\
\text { microbiota differ } \\
\text { compositionally in some } \\
\text { women. } \\
\text { Non-lactobacillus dominant } \\
\text { endometrial microbiota may } \\
\text { be associated with negative } \\
\text { reproductive outcomes in } \\
\text { IVF patients. }\end{array}$ \\
\hline
\end{tabular}


Table 1. Cont.

\begin{tabular}{|c|c|c|c|c|c|c|}
\hline $\begin{array}{l}\text { Year and } \\
\text { First Author }\end{array}$ & Study Subjects & Study Region & Microbial Analysis & Sampling Method & $\begin{array}{l}\text { Dominant Uterine } \\
\text { Bacterial Organisms }\end{array}$ & Main Findings \\
\hline $\begin{array}{l}2016 \\
\text { Verstraelen [43] }\end{array}$ & 19 women of reproductive age & Belgium & 16S rRNA Seq (V1-2) & $\begin{array}{l}\text { Transcervical sampling with } \\
\text { Tao brush with } \\
\text { cervicovaginal sheath }\end{array}$ & $\begin{array}{l}\text { Phyla: } \\
\text {-Bacteroidetes } \\
\text {-Proteobacteria } \\
\text {-Firmicutes }\end{array}$ & $\begin{array}{l}\text { The uterine cavity is } \\
\text { not sterile. }\end{array}$ \\
\hline $\begin{array}{l}2016 \\
\text { Walther-António } \\
{[50]}\end{array}$ & $\begin{array}{l}31 \text { women undergoing } \\
\text { hysterectomy for benign or } \\
\text { malignant uterine disease }\end{array}$ & United States & 16S rRNA Seq (V3-5) & $\begin{array}{l}\text { Sterile collection of uterine } \\
\text { swabs and tissue at time of } \\
\text { surgery }\end{array}$ & $\begin{array}{l}\text { Genera: } \\
\text {-Shigella } \\
\text {-Barnesiella } \\
\text {-Staphylococcus } \\
\text {-Blautia } \\
\text {-Parabacteroides } \\
\text {-Bacteroides } \\
\text {-Faecalibacterium }\end{array}$ & $\begin{array}{l}\text { The uterine cavity is not } \\
\text { sterile. } \\
\text { Specific bacteria present in } \\
\text { the upper FRT may be } \\
\text { associated with gynecologic } \\
\text { malignancy. }\end{array}$ \\
\hline $\begin{array}{l}2017 \\
\text { Chen [11] }\end{array}$ & $\begin{array}{l}95 \text { reproductive age women } \\
\text { undergoing hysterectomy } \\
\text { for benign uterine disease } \\
\text { not known to involve } \\
\text { infection }\end{array}$ & China & 16S rRNA Seq (V4-5) & $\begin{array}{l}\text { Sterile collection of swabs } \\
\text { from uterine cavity at time } \\
\text { of surgery (additional } \\
\text { vaginal and cervical swabs } \\
\text { obtained prior to surgery) }\end{array}$ & $\begin{array}{l}\text { Genera: } \\
\text {-Lactobacillus }(31 \%) \\
\text {-Others }(11 \%) \\
\text {-Acinetobacter }(9 \%) \\
\text {-Pseudomonas }(9 \%)\end{array}$ & $\begin{array}{l}\text { The uterine cavity and } \\
\text { upper FRT are not sterile. } \\
\text { There is a continuum of } \\
\text { microbiota from the lower to } \\
\text { upper FRT with decreasing } \\
\text { biomass, decreasing } \\
\text { Lactobacillus abundance, and } \\
\text { increasing diversity towards } \\
\text { upper FRT. }\end{array}$ \\
\hline $\begin{array}{l}2017 \\
\text { Miles [48] }\end{array}$ & $\begin{array}{l}10 \text { women undergoing } \\
\text { hysterectomy and bilateral } \\
\text { salpingo-ophorectomy for } \\
\text { benign }(n=8) \text { or malignant } \\
(n=2) \text { conditions }\end{array}$ & United States & 16S rRNA Seq (V1-3) & $\begin{array}{l}\text { Sterile collection of tissue } \\
\text { and swabs from uterine } \\
\text { cavity at time of surgery }\end{array}$ & $\begin{array}{l}\text { Genera: } \\
\text {-Lactobacillus } \\
\text {-Other } \\
\text {-Corynebacterium } \\
\text {-Staphylococcus } \\
\text {-Blautia }\end{array}$ & $\begin{array}{l}\text { The uterine cavity and } \\
\text { upper FRT are not sterile. }\end{array}$ \\
\hline $\begin{array}{l}2017 \\
\text { Tao [39] }\end{array}$ & $\begin{array}{l}70 \text { women undergoing IVF } \\
\text { embryo transfers }\end{array}$ & United States & 16S rRNA Seq (V4) & $\begin{array}{l}\text { Transcervical IVF } \\
\text { catheter-tip sampling }\end{array}$ & $\begin{array}{l}\text { Genera: } \\
\text {-Lactobacillus } \\
\text {-Corynebacterium } \\
\text {-Bifidobacterium } \\
\text {-Staphylococcus } \\
\text {-Streptococcus }\end{array}$ & $\begin{array}{l}\text { IVF catheter-tip sampling } \\
\text { provides data on the low } \\
\text { biomass uterine microbiome. }\end{array}$ \\
\hline
\end{tabular}


Table 1. Cont.

\begin{tabular}{|c|c|c|c|c|c|c|}
\hline $\begin{array}{l}\text { Year and } \\
\text { First Author }\end{array}$ & Study Subjects & Study Region & Microbial Analysis & Sampling Method & $\begin{array}{l}\text { Dominant Uterine } \\
\text { Bacterial Organisms }\end{array}$ & Main Findings \\
\hline $\begin{array}{l}2018 \\
\text { Liu [59] }\end{array}$ & $\begin{array}{l}25 \text { women with recurrent } \\
\text { pregnancy loss treated at } \\
\text { IVF clinic }\end{array}$ & China & 16S rRNA Seq (V4) & $\begin{array}{l}\text { Transcervical sheathed } \\
\text { catheter endometrial fluid } \\
\text { and tissue sampling }\end{array}$ & $\begin{array}{l}\text { Genera: } \\
\text {-Lactobacillus } \\
\text {-Gardnerella } \\
\text {-Atopobium } \\
\text {-Bifidobacterium }\end{array}$ & $\begin{array}{l}\text { The uterine cavity is not } \\
\text { sterile. } \\
\text { Endometrial fluid sampling } \\
\text { may not fully reflect } \\
\text { microbiome composition in } \\
\text { endometrial tissue. }\end{array}$ \\
\hline $\begin{array}{l}2018 \\
\text { Wee [45] }\end{array}$ & $\begin{array}{l}31 \text { women undergoing } \\
\text { hysteroscopy for benign } \\
\text { indications, with and } \\
\text { without history of infertility }\end{array}$ & Australia & 16S rRNA Seq (V1-V3) & $\begin{array}{l}\text { Transcervical endometrial } \\
\text { tissue biopsy (curette) }\end{array}$ & $\begin{array}{l}\text { Genera: } \\
\text {-Lactobacillus } \\
\text {-Bifidobacterium } \\
\text {-Corynebacterium } \\
\text {-Gardnerella } \\
\text {-Propionibacterium } \\
\text {-Propionimicrobium }\end{array}$ & $\begin{array}{l}\text { The uterine cavity is not } \\
\text { sterile. Bacterial abundances } \\
\text { differ between the upper } \\
\text { and lower FRT, and } \\
\text { composition may differ by } \\
\text { fertility status. }\end{array}$ \\
\hline $\begin{array}{l}2019 \\
\text { Walsh [49] }\end{array}$ & $\begin{array}{l}148 \text { women undergoing } \\
\text { hysterectomy for benign } \\
\text { disease, endometrial } \\
\text { hyperplasia, or endometrial } \\
\text { cancer }\end{array}$ & United States & 16S rRNA Seq (V3-5) & $\begin{array}{l}\text { Sterile collection of uterine } \\
\text { swabs and tissue at time of } \\
\text { surgery }\end{array}$ & $\begin{array}{l}\text { Phyla: } \\
\text {-Firmicutes } \\
\text {-Bacteroidetes } \\
\text {-Actinobacteria }\end{array}$ & $\begin{array}{l}\text { The uterine cavity is not } \\
\text { sterile. } \\
\text { The FRT microbiome is } \\
\text { significantly different } \\
\text { between patients with and } \\
\text { without endometrial cancer. } \\
\text { The lower and upper FRT } \\
\text { microbiome are correlated. }\end{array}$ \\
\hline $\begin{array}{l}2019 \\
\text { Winters [46] }\end{array}$ & $\begin{array}{l}25 \text { pre-menopausal women } \\
\text { undergoing hysterectomy } \\
\text { for benign uterine disease }\end{array}$ & Italy & $\begin{array}{l}\text { 16S rRNA Seq (V4); and } \\
\text { universal and } \\
\text { Lactobacillus-targeted 16S } \\
\text { rRNA qPCR }\end{array}$ & $\begin{array}{l}\text { Sterile collection of uterine } \\
\text { swabs at time of surgery. } \\
\text { Additional collection of } \\
\text { vaginal, cervical, rectal, and } \\
\text { oral swabs }\end{array}$ & $\begin{array}{l}\text { Genera: } \\
\text {-Acinetobacter } \\
\text {-Pseudomonas } \\
\text {-Cloacibacterium } \\
\text {-Comamonadaceae }\end{array}$ & $\begin{array}{l}\text { The uterine cavity is not } \\
\text { sterile. The uterine } \\
\text { microbiome most closely } \\
\text { resembles the cervical } \\
\text { microbiome but differs from } \\
\text { the vaginal microbiome and } \\
\text { is not dominated by } \\
\text { Lactobacillus. }\end{array}$ \\
\hline
\end{tabular}


Table 1. Cont.

\begin{tabular}{|c|c|c|c|c|c|c|}
\hline $\begin{array}{l}\text { Year and } \\
\text { First Author }\end{array}$ & Study Subjects & Study Region & Microbial Analysis & Sampling Method & $\begin{array}{l}\text { Dominant Uterine } \\
\text { Bacterial Organisms }\end{array}$ & Main Findings \\
\hline $\begin{array}{l}2019 \\
\text { Zhou } \\
{[60]}\end{array}$ & $\begin{array}{l}25 \text { women with ovarian } \\
\text { cancer and } 25 \text { women } \\
\text { undergoing } \\
\text { salpingo-oophorectomy for } \\
\text { benign uterine disease }\end{array}$ & China & 16S rRNA Seq (V3-4) & $\begin{array}{l}\text { Sterile collection of ovarian } \\
\text { cancer and normal distal } \\
\text { fallopian tube tissue at the } \\
\text { time of surgery }\end{array}$ & Not assessed & $\begin{array}{l}\text { The upper FRT is not sterile. } \\
\text { Proteobacteria and } \\
\text { Firmicutes are the most } \\
\text { frequent taxa in ovarian } \\
\text { cancer and normal fallopian } \\
\text { tubes, with differences at the } \\
\text { phylum/genus level. }\end{array}$ \\
\hline $\begin{array}{l}2020 \\
\text { Riganelli [44] }\end{array}$ & $\begin{array}{l}34 \text { reproductive age women } \\
\text { undergoing infertility } \\
\text { treatment }\end{array}$ & Italy & 16S rRNA Seq (V3-4) & $\begin{array}{l}\text { Transcervical endometrial } \\
\text { tissue biopsy (pipelle) using } \\
\text { a vaginal and cervical sheath }\end{array}$ & $\begin{array}{l}\text { Phyla: } \\
\text {-Firmicutes } \\
\text {-Proteobacteria } \\
\text {-Bacteroidetes } \\
\text {-Actinobacteria }\end{array}$ & $\begin{array}{l}\text { The uterine cavity is not } \\
\text { sterile. } \\
\text { The uterine microbiome is } \\
\text { compositionally different } \\
\text { from the vaginal } \\
\text { microbiome. }\end{array}$ \\
\hline $\begin{array}{l}2021 \\
\mathrm{Lu}[47]\end{array}$ & $\begin{array}{l}50 \text { women undergoing } \\
\text { hysterectomy for benign } \\
\text { disease or endometrial } \\
\text { cancer }\end{array}$ & China & 16S rRNA Seq (V3-4) & $\begin{array}{l}\text { Sterile collection of uterine } \\
\text { swabs and tissue at time of } \\
\text { surgery, noted sterile } \\
\text { instruments used }\end{array}$ & $\begin{array}{l}\text { Genera: } \\
\text {-Rhodococcus } \\
\text {-Phyllobacterium } \\
\text {-Sphingomonas } \\
\text {-Bacteroides } \\
\text {-Bifidobacterium }\end{array}$ & $\begin{array}{l}\text { The uterine cavity is not } \\
\text { sterile. } \\
\text { The uterine microbiome } \\
\text { differed in diversity and } \\
\text { composition between } \\
\text { endometrial cancer and } \\
\text { benign disease. }\end{array}$ \\
\hline
\end{tabular}




\subsection{Endometrial Cancer and the FRT Microbiome}

Endometrial adenocarcinoma is the most common cancer of the female reproductive tract in the Western world, with an estimated 60,000 new cases and 12,000 deaths in the United States in 2021 [18]. As the US population undergoes demographic changes leading to increased life expectancy and higher prevalence of key risk factors such as obesity, the incidence of endometrial cancer is rising and a disproportionate increase in aggressive non-endometrioid subtypes is projected to worsen outcomes. Endometrial cancer is increasingly appreciated to represent a heterogeneous group of cancer subtypes that share the endometrium as an organ of origin but are driven by diverse molecular mechanisms. The Cancer Genome Atlas (TCGA) established four molecular subtypes of endometrial cancer with prognostic relevance [61,62]. The presence and extent of antitumor immune responses have emerged as strong prognostic and predictive markers in solid malignancies, including endometrial cancer $[63,64]$. However, little is known about how this relates to tumor immunology, the upper FRT mucosal microenvironment, and resident microbiome. The majority of studies on the upper FRT microbiome have been conducted in healthy women or those with benign uterine disease such as endometriosis or uterine fibroids, and only three published studies to date reported on the FRT microbiome of women with endometrial cancer compared to healthy controls $[47,49,50]$.

In 2016, Walther-António et al. reported a first cross-sectional study from a US tertiary care center including 31 women undergoing hysterectomy for endometrial cancer $(n=17)$, endometrial hyperplasia $(n=4)$, or benign uterine disease $(n=10)$. The authors found a higher degree of FRT microbial diversity in women with endometrial cancer compared to that of healthy controls, and enrichment of particular taxa such as Firmicutes, Spirochaetes, Actinobacteria, Bacteroidetes, and Proteobacteria [50]. A subsequent larger study by the same group comprised 148 women, including 66 with endometrial cancer, 7 with atypical endometrial hyperplasia, and 75 with benign uterine disease, and represents the largest study of the FRT microbiome in endometrial cancer to date. The authors confirmed their earlier findings of increased diversity of the upper FRT microbiome in patients with endometrial cancer compared to that of healthy controls [49]. Interestingly, the authors found that changes in lower FRT rather than upper FRT microbiome profiles demonstrated the strongest association with endometrial cancer. In addition, FRT microbiome changes were related to other risk factors of endometrial cancer, such as age, menopausal status, and obesity [49].

A recent study in a Chinese cohort of 50 women undergoing surgery for benign uterine disease $(n=25)$ or endometrial cancer $(n=25)$ reported some conflicting findings [47]. $\mathrm{Lu}$ et al. detected similar phyla in greater abundance in the upper FRT of endometrial cancer patients compared to those with benign uterine disease, including Proteobacteria, Actinobacteria, Firmicutes, and Bacteroidetes, with Micrococcus being most significantly increased in endometrial cancer at the genus level. However, in contrast to the two earlier studies by Walther-António and colleagues, they reported a lower diversity of FRT microbiomes in association with endometrial cancer. This study also reported increased gene expression of three inflammatory cytokines, IL-6, IL-8, and IL-17, in endometrial tissues from cancer patients compared to patients with benign disease, and a positive correlation between cytokine expression and the relative abundance of Micrococcus [47]. Observations in a single endometrial cancer cell line in vitro suggest that co-culture with Atopobium spp. and Porphyromonas spp. can induce expression of proinflammatory cytokines in HEC-1A endometrial cancer cells [65], warranting further investigation. Findings that microbial populations in the vagina and lower FRT are related to factors long known to be associated with endometrial cancer risk such as menopausal status [66-68], obesity [69], pelvic inflammatory disease [70], and race [71-75] further support a correlative, if not yet causative, relationship between changes in the FRT microbiome and the development of endometrial cancer.

In summary, the existing literature suggests an association between the FRT microbiome and endometrial cancer, but it does not yet allow conclusions about whether this 
may represent cause or consequence. Future studies providing causative and mechanistic insight into the functional relationship between FRT microbiome and endometrial cancer development and progression will be critical in understanding how we may leverage this knowledge for personalized medicine including FRT microbiome-targeted interventions.

\subsection{Ovarian Cancer and the FRT Microbiome}

Among all gynecologic cancers, the least data exists on the relationship between ovarian cancer and the FRT microbiome. Ovarian cancer is the least common but most lethal of all gynecologic cancers with 21,000 newly diagnosed cases and 14,000 deaths each year in the United States and $>150,000$ deaths worldwide each year [76]. The lack of effective screening tests and non-specific symptoms contribute to diagnosis at later stages and poor outcome [77]. The peritoneal cavity, where ovarian cancer arises and spreads, has long been considered a sterile environment under physiologic conditions, but this view has recently been challenged. There is emerging evidence of microbial colonization of the peritoneum and correlation between the peritoneal and upper and lower FRT microbiome within an individual [11]. This suggests that FRT health and dysbiosis may influence inflammation and immune response within the peritoneal cavity and consequently may affect development and progression of cancers arising and spreading in the peritoneal cavity, one of the most common being ovarian cancer.

A recent ovarian cancer case-control study of 580 European women assessed the cervicovaginal microbiome in cytological ThinPrep samples by $16 \mathrm{~S}$ rRNA sequencing [78]. This study cohort included 176 ovarian cancer patients, 109 women without cancer but with known BRCA1 mutations, and 295 healthy controls from the United Kingdom, Italy, Germany, Norway, and the Czech Republic. The authors found that the presence of ovarian cancer and known risk factors including BRCA1 mutation and older age were significantly associated with non-Lactobacillus dominant cervicovaginal microbiomes [78]. Limitations of this study include the lack of microbiome analysis of the upper FRT, where ovarian cancer originates, and the use of ThinPrep samples commonly obtained in a methanol-based fixative, which may have altered the results of microbiome analysis.

Zhou et al. [60] studied the intratumoral ovarian cancer microbiome by $16 \mathrm{~S}$ rRNA sequencing in 25 fresh tumor samples of high grade serous ovarian cancer compared to 25 normal distal fallopian tubes from healthy women. The authors found a similar microbial abundance but slightly decreased diversity in ovarian cancer versus normal tissue. Proteobacteria and Firmicutes were the most frequent taxa identified in both tumor and normal samples, with differences in the relative proportions of certain phyla. At the genus level, this study observed an enrichment of Acinetobacter in ovarian cancer and enrichment of Lactococcus in normal fallopian tube tissues [60]. This study further supports the presence of an upper FRT microbiome in sterilely collected samples from ovaries and fallopian tubes. However, the descriptive nature of the study does not allow conclusions about whether changes in bacterial abundance and composition are a cause or consequence of ovarian cancer development. One study of routine formalin-fixed and paraffin-embedded archival pathological tissues found distinct viral and bacterial profiles in ovarian cancer compared to those of matched and non-matched normal controls; however, the use of non-sterilely collected paraffin-embedded samples holds the potential for sample contamination, and the use of a microarray platform primarily focused on viral detection and including only probes for 320 bacteria provides only limited insight into tumor microbial profiles [79]. A small study found decreased microbial diversity and a unique microbial profile in the peritoneal fluid of 10 ovarian cancer patients compared to 20 patients with benign ovarian lesions [80]. A set of 18 microbial organizational taxonomic units was enriched in women with ovarian cancer, including bacteria of gut microbial origin and with predicted functionality centered around inflammatory mediators. Interestingly, the addition of peritoneal microbial features increased the accuracy of common serum tumor markers such as CA-125 for the diagnosis of ovarian cancer in this limited cohort of 30 patients [80]. 
Despite the current lack of functional microbiome analysis and established causative relationships, the observed associations between FRT microbial dysbiosis and ovarian cancer risk warrant further research exploring FRT and peritoneal microbiome as potential adjuncts to ovarian cancer prevention, diagnosis, and treatment.

\section{Interventions Targeting the FRT Microbiome and Implications for Personalized Medicine}

The FRT microbiome has been demonstrated to be modifiable through lifestyle factors, including diet, smoking, exercise, hygiene, and sexual practices, and hormone status [81-83]. The loss of estrogen in the vaginal epithelium either from natural menopause or the results of hormonal or cytotoxic cancer therapies induces a shift towards non-Lactobacillus dominant lower FRT microbiomes with increased abundance of anaerobes such as Gardnerella and Atopobium. In addition, there is evidence that other body sites including oral and perianal mucosa [52-54] and sexual partners [52,84] may act as a reservoir for the FRT microbiome, which needs to be taken into consideration when designing interventions. To date, interventions manipulating the FRT microbiome have not yet been explored in the setting of gynecologic cancers, and therapies targeting the lower FRT microbiome have been focused on treatment of vaginal microbial dysbiosis/bacterial vaginosis. Nevertheless, experiences from treating bacterial vaginosis may provide a proof of principle for designing future interventions modulating the FRT microbiome in the context of prevention or treatment of gynecologic cancers.

\subsection{Treatment of Vaginal Microbial Dysbiosis or Bacterial Vaginosis}

Treatment of bacterial vaginosis (BV) is mostly limited to antibiotic options, including metronidazole or clindamycin, which lead to only a transient resolution, with approximately $50 \%$ of women having a recurrence within one year post-treatment [85]. The promotion of growth of Lactobacillus species in the vaginal tract may be multifaceted and include the removal of BV associated bacteria, but also the degradation of the protective biofilm formation by BV-associated bacteria such as Gardnerella vaginalis, or the presence and promotion of sufficient Lactobacillus bacteria to generate lactate or hydrogen peroxide that will decrease the mucosal $\mathrm{pH}$. Other treatment options have been explored in clinical practice in addition to antibiotic treatment, such as using boric acid [86,87] or probiotics/prebiotics that promote a more favorable vaginal microbiome composition [88]. Boric acid has been used in a few clinical trials to treat recurrent BV and was found to be well tolerated as an intravaginal application [86,89]. The mechanism by which it alleviates symptomatic BV is thought to be through the inhibition of biofilm formation, which may decrease host inflammation in the mucosal site, promoting epithelial repair. The presence of biofilms may also decrease the ability of host antibodies to reach BV-associated bacteria, and therefore decreasing this physical barrier may promote antibody activity.

Numerous different probiotics are available for use to the public that are advertised as a treatment for BV, and clinical studies have shown some success using oral or vaginal probiotics to treat recurrent BV $[88,90,91]$. The addition of probiotics may promote Lactobacillus stability, increasing the presence of immunomodulatory products such as hydrogen peroxide and lactic acid, decreasing inflammation. Recently, there have been studies evaluating live biotherapeutic products [92,93] or vaginal microbiome transplants [94] as therapeutic options for recurrent BV. The first vaginal microbiome-based live biotherapeutic product, named Lactin- $\mathrm{V}$, uses a strain of Lactobacillus crispatus isolated from the vagina of a healthy woman [93]. In a randomized, double-blind, placebo-controlled phase $2 \mathrm{~b}$ trial, recurrent BV was found in $30 \%$ of women in the Lactin-V treated group and $45 \%$ in the placebo group after 12 weeks, and there were no adverse effects recorded to be greater in the treated group than the placebo group. The first vaginal microbiome transplant was performed on 5 patients, with 4 observing long term remission (21 months) after treatment [94]. No adverse effects were observed in this study. However, three patients required repeated microbiota transplant procedures to work effectively, and one had to use a different donor to achieve a stable Lactobacillus vaginal microbiome after a second treatment. This indicates 
vaginal microbiome transplants are a complex treatment option that would be personalized on a case-by-case basis and not necessarily appropriate for a global treatment option.

Lessons from treating vaginal microbial dysbiosis suggest that maintenance of a healthy FRT microbiome is complex, and future interventions may require combinatorial approaches targeting the microbiota along with the mucosal microenvironment including immunomodulatory microbial metabolites and host immune response to achieve a lasting therapeutic modulation of the FRT microbiome.

\subsection{FRT Microbiome and Cancer Therapy}

There are no published studies yet demonstrating an impact of the FRT microbiome on response to treatment of gynecologic cancers. Changes in the vaginal and cervical microbiome were observed following pelvic radiation therapy, a commonly used primary or adjuvant treatment for cervical and endometrial cancer $[95,96]$. However, possible associations between the FRT microbiome and treatment response were not assessed in these small pilot studies.

Associations have been recently reported between antibiotic treatment and the outcome of women with gynecologic cancers undergoing chemotherapy or immunotherapy. In a retrospective study of 424 women with advanced stage epithelial ovarian cancer who underwent surgery and platinum-based chemotherapy, receiving antibiotic treatment against gram-positive organisms for at least $48 \mathrm{~h}$ during chemotherapy was associated with decreased progression-free and overall survival [97]. Similarly, in a retrospective study of 101 recurrent endometrial, ovarian, and cervical cancer patients, pre-treatment with antibiotics within the 30 days prior to treatment, but not during treatment, with immune checkpoint inhibitors was associated with decreased response rate and shorter progression-free and overall survival [98]. Further studies are needed to validate the adverse effect of antibiotic treatment on response to cancer chemotherapy or immunotherapy, its dependence on timing relative to cancer therapy, and whether its effect is mediated through changes in the gut or FRT microbiome or both.

Increasing evidence has implicated the gut microbiome in modulating the response to cancer immunotherapies [4,5], and early phase clinical trials have demonstrated successful gut microbiome-targeted interventions to improve treatment response. Therapeutic modulation of the gut microbiome such as bacterial supplementation with Akkermansia [99] or fecal microbiota transplants derived from donors with prior favorable response to cancer immunotherapy [100] have been shown to overcome resistance to checkpoint inhibitors such as anti-PD-1 therapy in previous non-responders. These studies also found unique proteomic and metabolomic signatures in the tumor microenvironment, suggesting the effect is therapeutically transferrable [100].

Together, these prior reports demonstrating the importance of the gut microbiome for modulating responses to cancer treatment including chemotherapy and immunotherapy provide a rationale for exploring similar effects of the FRT microbiome in future studies.

\section{Perspective and Future Directions}

We deliberately focused our review on microbiome data from human cohorts, and a discussion of FRT microbiome of in vivo or in vitro models of gynecologic cancers was beyond the scope of this article. In conclusion, we have discussed the evidence supporting the existence of an upper FRT and uterine microbiome and emerging evidence suggesting its interplay with local inflammation and host immune responses. Despite the current lack of mechanistic insight, observed associations between changes in the FRT microbiome and the development, progression, and outcome of gynecologic cancers warrant further studies. Evidence demonstrating the importance of the gut microbiome for response to cancer treatments and early success of gut microbiome-targeted interventions lay the groundwork to explore FRT microbiome-targeted interventions. The FRT microbiome has been demonstrated to be modifiable through nutritional interventions, probiotic and live biotherapeutic products, and vaginal microbiota transplants. If causative relationships to carcinogenesis 
can be established, microbiome-targeted interventions might aid in primary and secondary preventions of gynecologic cancers or be able to modulate and enhance responses to conventional cancer therapies. Future studies should include multi-omics approaches including metagenomics, metaproteomics, and metabolomics for functional analysis of the FRT microbiome to gain mechanistic insight and identify targets for personalized medicine.

Author Contributions: All authors contributed to writing and editing of the manuscript. All authors have read and agreed to the published version of the manuscript.

Funding: This research received no external funding.

Institutional Review Board Statement: Not applicable.

Informed Consent Statement: Not applicable.

Data Availability Statement: Not applicable.

Acknowledgments: This work was supported by the Norma C. and Albert I. Geller Designated Professorship in Ovarian Cancer Research (to S. Avril) and the Adel Mahmoud Professorship of Global Health and Vaccines (to A. Burgener).

Conflicts of Interest: The authors declare no conflict of interest.

\section{References}

1. Turnbaugh, P.J.; Ley, R.E.; Hamady, M.; Fraser-Liggett, C.M.; Knight, R.; Gordon, J.I. The Human Microbiome Project. Nature 2007, 449, 804-810. [CrossRef] [PubMed]

2. Integrative HMP (iHMP) Research Network Consortium. The Integrative Human Microbiome Project: Dynamic Analysis of Microbiome-Host Omics Profiles during Periods of Human Health and Disease. Cell Host Microbe 2014, 16, 276-289. [CrossRef] [PubMed]

3. Chow, J.; Lee, S.M.; Shen, Y.; Khosravi, A.; Mazmanian, S.K. Host-Bacterial Symbiosis in Health and Disease. Adv. Immunol. 2010, 107, 243-274. [CrossRef] [PubMed]

4. Vétizou, M.; Pitt, J.M.; Daillère, R.; Lepage, P.; Waldschmitt, N.; Flament, C.; Rusakiewicz, S.; Routy, B.; Roberti, M.P.; Duong, C.P.M.; et al. Anticancer immunotherapy by CTLA-4 blockade relies on the gut microbiota. Science 2015, 350, 1079-1084. [CrossRef] [PubMed]

5. Gopalakrishnan, V.; Spencer, C.N.; Nezi, L.; Reuben, A.; Andrews, M.C.; Karpinets, T.V.; Prieto, P.A.; Vicente, D.; Hoffman, K.; Wei, S.C.; et al. Gut microbiome modulates response to anti-PD-1 immunotherapy in melanoma patients. Science 2018, 359, 97-103. [CrossRef]

6. Cancer Stat Facts: Uterine Cancer. Available online: https://seer.cancer.gov/statfacts/html/corp.html (accessed on 12 February 2021).

7. Cancer Stat Facts: Vulvar Cancer. Available online: https://seer.cancer.gov/statfacts/html/vulva.html (accessed on 5 December 2020).

8. Cancer Stat Facts: Cervical Cancer. Available online: https:// seer.cancer.gov/statfacts/html/cervix.html (accessed on 12 February 2021).

9. Cancer Stat Facts: Ovarian Cancer. Available online: https://seer.cancer.gov/statfacts/html/ovary.html (accessed on 12 February 2021).

10. Mitchell, C.M.; Haick, A.; Nkwopara, E.; Garcia, R.; Rendi, M.; Agnew, K.; Fredricks, D.N.; Eschenbach, D. Colonization of the upper genital tract by vaginal bacterial species in nonpregnant women. Am. J. Obstet. Gynecol. 2015, 212, 611.e1-611.e9. [CrossRef] [PubMed]

11. Chen, C.; Song, X.; Chunwei, Z.; Zhong, H.; Dai, J.; Lan, Z.; Li, F.; Yu, X.; Feng, Q.; Wang, Z.; et al. The microbiota continuum along the female reproductive tract and its relation to uterine-related diseases. Nat. Commun. 2017, 8, 1-11. [CrossRef]

12. Ravel, J.; Gajer, P.; Abdo, Z.; Schneider, G.M.; Koenig, S.S.K.; McCulle, S.L.; Karlebach, S.; Gorle, R.; Russell, J.; Tacket, C.O.; et al. Vaginal microbiome of reproductive-age women. Proc. Natl. Acad. Sci. USA 2011, 108, 4680-4687. [CrossRef] [PubMed]

13. Anahtar, M.N.; Gootenberg, D.B.; Mitchell, C.M.; Kwon, D.S. Cervicovaginal Microbiota and Reproductive Health: The Virtue of Simplicity. Cell Host Microbe 2018, 23, 159-168. [CrossRef]

14. Aldunate, M.; Srbinovski, D.; Hearps, A.C.; Latham, C.F.; Ramsland, P.A.; Gugasyan, R.; Cone, R.A.; Tachedjian, G. Antimicrobial and immune modulatory effects of lactic acid and short chain fatty acids produced by vaginal microbiota associated with eubiosis and bacterial vaginosis. Front. Physiol. 2015, 6, 164. [CrossRef]

15. Witkin, S.S.; Mendes-Soares, H.; Linhares, I.M.; Jayaram, A.; Ledger, W.J.; Forney, L.J. Influence of Vaginal Bacteria and d and 1-Lactic Acid Isomers on Vaginal Extracellular Matrix Metalloproteinase Inducer: Implications for Protection against Upper Genital Tract Infections. MBio 2013, 4, e00460-13. [CrossRef] [PubMed]

16. Amabebe, E.; Anumba, D.O.C. The Vaginal Microenvironment: The Physiologic Role of Lactobacilli. Front. Med. $2018,5,181$. [CrossRef]

17. Shannon, B.; Gajer, P.; Yi, T.J.; Ma, B.; Humphrys, M.S.; Thomas-Pavanel, J.; Chieza, L.; Janakiram, P.; Saunders, M.; Tharao, W.; et al. Distinct Effects of the Cervicovaginal Microbiota and Herpes Simplex Type 2 Infection on Female Genital Tract Immunology. J. Infect. Dis. 2017, 215, 1366-1375. [CrossRef] 
18. Anahtar, M.N.; Byrne, E.H.; Doherty, K.E.; Bowman, B.A.; Yamamoto, H.S.; Soumillon, M.; Padavattan, N.; Ismail, N.; Moodley, A.; Sabatini, M.E.; et al. Cervicovaginal Bacteria Are a Major Modulator of Host Inflammatory Responses in the Female Genital Tract. Immunity 2015, 42, 965-976. [CrossRef] [PubMed]

19. Burgener, A.; McGowan, I.; Klatt, N.R. HIV and mucosal barrier interactions: Consequences for transmission and pathogenesis. Curr. Opin. Immunol. 2015, 36, 22-30. [CrossRef] [PubMed]

20. Marconi, C.; Santos-Greatti, M.M.; Parada, C.M.; Pontes, A.; Pontes, A.G.; Giraldo, P.C.; Donders, G.; Da Silva, M.G. Cervicovaginal Levels of Proinflammatory Cytokines Are Increased During Chlamydial Infection in Bacterial Vaginosis But Not in Lactobacilli-Dominated Flora. J. Low. Genit. Tract Dis. 2014, 18, 261-265. [CrossRef] [PubMed]

21. Masson, L.; Mlisana, K.; Little, F.; Werner, L.; Mkhize, N.N.; Ronacher, K.; Gamieldien, H.; Williamson, C.; McKinnon, L.R.; Walzl, G.; et al. Defining genital tract cytokine signatures of sexually transmitted infections and bacterial vaginosis in women at high risk of HIV infection: A cross-sectional study. Sex. Transm. Infect. 2014, 90, 580-587. [CrossRef] [PubMed]

22. Zevin, A.S.; Xie, I.Y.; Birse, K.; Arnold, K.; Romas, L.; Westmacott, G.; Novak, R.M.; McCorrister, S.; McKinnon, L.R.; Cohen, C.R.; et al. Microbiome Composition and Function Drives Wound-Healing Impairment in the Female Genital Tract. PLoS Pathog. 2016, 12, e1005889. [CrossRef]

23. Srinivasan, S.; Morgan, M.; Fiedler, T.L.; Djukovic, D.; Hoffman, N.G.; Raftery, D.; Marrazzo, J.; Fredricks, D.N. Metabolic Signatures of Bacterial Vaginosis. MBio 2015, 6, e00204-15. [CrossRef]

24. Mirmonsef, P.; Zariffard, M.R.; Gilbert, D.; Makinde, H.-K.; Landay, A.L.; Spear, G.T. Short-Chain Fatty Acids Induce ProInflammatory Cytokine Production Alone and in Combination with Toll-Like Receptor Ligands. Am. J. Reprod. Immunol. 2011, 67, 391-400. [CrossRef]

25. Atashili, J.; Poole, C.; Ndumbe, P.M.; Adimora, A.A.; Smith, J.S. Bacterial vaginosis and HIV acquisition: A meta-analysis of published studies. AIDS 2008, 22, 1493-1501. [CrossRef] [PubMed]

26. Svare, J.; Schmidt, H.; Hansen, B.; Lose, G. Bacterial vaginosis in a cohort of Danish pregnant women: Prevalence and relationship with preterm delivery, low birthweight and perinatal infections. BJOG Int. J. Obstet. Gynaecol. 2006, 113, 1419-1425. [CrossRef]

27. Torrone, E.A.; Morrison, C.S.; Chen, P.-L.; Kwok, C.; Francis, S.C.; Hayes, R.J.; Looker, K.J.; McCormack, S.; McGrath, N.; Van De Wijgert, J.H.H.M.; et al. Prevalence of sexually transmitted infections and bacterial vaginosis among women in sub-Saharan Africa: An individual participant data meta-analysis of 18 HIV prevention studies. PLoS Med. 2018, 15, e1002511. [CrossRef] [PubMed]

28. Shannon, B.; Yi, T.J.; Perusini, S.; Gajer, P.; Ma, B.; Humphrys, M.S.; Thomas-Pavanel, J.; Chieza, L.; Janakiram, P.; Saunders, M.; et al. Association of HPV infection and clearance with cervicovaginal immunology and the vaginal microbiota. Mucosal Immunol. 2017, 10, 1310-1319. [CrossRef] [PubMed]

29. King, C.C.; Jamieson, D.; Wiener, J.; Cu-Uvin, S.; Klein, R.S.; Rompalo, A.M.; Shah, K.V.; Sobel, J.D. Bacterial Vaginosis and the Natural History of Human Papillomavirus. Infect. Dis. Obstet. Gynecol. 2011, 2011, 1-8. [CrossRef] [PubMed]

30. Mitra, A.; Macintyre, D.A.; Lee, Y.S.; Smith, A.; Marchesi, J.; Lehne, B.; Bhatia, R.; Lyons, D.; Paraskevaidis, E.; Li, J.V.; et al. Cervical intraepithelial neoplasia disease progression is associated with increased vaginal microbiome diversity. Sci. Rep. 2015, 5, 16865. [CrossRef] [PubMed]

31. McKinnon, L.R.; Achilles, S.; Bradshaw, C.S.; Burgener, A.; Crucitti, T.; Fredricks, D.N.; Jaspan, H.B.; Kaul, R.; Kaushic, C.; Klatt, N.; et al. The Evolving Facets of Bacterial Vaginosis: Implications for HIV Transmission. AIDS Res. Hum. Retrovir. 2019, 35, 219-228. [CrossRef]

32. Peebles, K.; Velloza, J.; Balkus, J.E.; McClelland, R.S.; Barnabas, R.V. High Global Burden and Costs of Bacterial Vaginosis: A Systematic Review and Meta-Analysis. Sex. Transm. Dis. 2019, 46, 304-311. [CrossRef]

33. Bilardi, J.E.; Walker, S.; Temple-Smith, M.; McNair, R.; Mooney-Somers, J.; Bellhouse, C.; Fairley, C.K.; Chen, M.Y.; Bradshaw, C. The Burden of Bacterial Vaginosis: Women's Experience of the Physical, Emotional, Sexual and Social Impact of Living with Recurrent Bacterial Vaginosis. PLoS ONE 2013, 8, e74378. [CrossRef]

34. Lin, D.; Kouzy, R.; Jaoude, J.A.; Noticewala, S.S.; Medrano, A.Y.D.; Klopp, A.H.; Taniguchi, C.M.; Colbert, L.E. Microbiome factors in HPV-driven carcinogenesis and cancers. PLoS Pathog. 2020, 16, e1008524. [CrossRef] [PubMed]

35. Altmäe, S. Commentary: Uterine Microbiota: Residents, Tourists, or Invaders? Front. Immunol. 2018, 9, 1874. [CrossRef]

36. Baker, J.M.; Chase, D.M.; Herbst-Kralovetz, M.M. Uterine Microbiota: Residents, Tourists, or Invaders? Front. Immunol. 2018, 9 , 208. [CrossRef] [PubMed]

37. Łaniewski, P.; Ilhan, Z.E.; Herbst-Kralovetz, M.M. The microbiome and gynaecological cancer development, prevention and therapy. Nat. Rev. Urol. 2020, 17, 232-250. [CrossRef] [PubMed]

38. Franasiak, J.M.; Werner, M.D.; Juneau, C.R.; Tao, X.; Landis, J.; Zhan, Y.; Treff, N.R.; Scott, R.T. Endometrial microbiome at the time of embryo transfer: Next-generation sequencing of the $16 \mathrm{~S}$ ribosomal subunit. J. Assist. Reprod. Genet. 2015, 33, 129-136. [CrossRef]

39. Tao, X.; Franasiak, J.M.; Zhan, Y.; Scott, R.T.; Rajchel, J.; Bedard, J.; Newby, R.; Treff, N.R.; Chu, T. Characterizing the endometrial microbiome by analyzing the ultra-low bacteria from embryo transfer catheter tips in IVF cycles: Next generation sequencing (NGS) analysis of the $16 \mathrm{~S}$ ribosomal gene. Hum. Microbiome J. 2017, 3, 15-21. [CrossRef]

40. Moreno, I.; Codoñer, F.M.; Vilella, F.; Valbuena, D.; Martinez-Blanch, J.F.; Jimenez-Almazán, J.; Alonso, R.; Alamá, P.; Remohí, J.; Pellicer, A.; et al. Evidence that the endometrial microbiota has an effect on implantation success or failure. Am. J. Obstet. Gynecol. 2016, 215, 684-703. [CrossRef] [PubMed] 
41. Fang, R.L.; Chen, L.X.; Shu, W.S.; Yao, S.Z.; Wang, S.W.; Chen, Y.Q. Barcoded sequencing reveals diverse in-trauterine microbiomes in patients suffering with endometrial polyps. Am. J. Transl. Res. 2016, 8, 1581-1592. [PubMed]

42. Khan, K.N.; Fujishita, A.; Masumoto, H.; Muto, H.; Kitajima, M.; Masuzaki, H.; Kitawaki, J. Molecular detection of intrauterine microbial colonization in women with endometriosis. Eur. J. Obstet. Gynecol. Reprod. Biol. 2016, 199, 69-75. [CrossRef]

43. Verstraelen, H.; Vilchez-Vargas, R.; Desimpel, F.; Jauregui, R.; Vankeirsbilck, N.; Weyers, S.; Verhelst, R.; De Sutter, P.; Pieper, D.H.; Van De Wiele, T. Characterisation of the human uterine microbiome in non-pregnant women through deep sequencing of the V1-2 region of the 16S rRNA gene. PeerJ 2016, 4, e1602. [CrossRef]

44. Riganelli, L.; Iebba, V.; Piccioni, M.; Illuminati, I.; Bonfiglio, G.; Neroni, B.; Calvo, L.; Gagliardi, A.; Levrero, M.; Merlino, L.; et al. Structural Variations of Vaginal and Endometrial Microbiota: Hints on Female Infertility. Front. Cell. Infect. Microbiol. 2020, 10, 350. [CrossRef]

45. Wee, B.A.; Thomas, M.; Sweeney, E.; Frentiu, F.; Samios, M.; Ravel, J.; Gajer, P.; Myers, G.; Timms, P.; Allan, J.A.; et al. A retrospective pilot study to determine whether the reproductive tract microbiota differs between women with a history of infertility and fertile women. Aust. N. Z. J. Obstet. Gynaecol. 2018, 58, 341-348. [CrossRef] [PubMed]

46. Winters, A.D.; Romero, R.; Gervasi, M.T.; Gomez-Lopez, N.; Tran, M.R.; Garcia-Flores, V.; Pacora, P.; Jung, E.; Hassan, S.S.; Hsu, C.-D.; et al. Does the endometrial cavity have a molecular microbial signature? Sci. Rep. 2019, 9, 1-17. [CrossRef] [PubMed]

47. Lu, W.; He, F.; Lin, Z.; Liu, S.; Tang, L.; Huang, Y.; Hu, Z. Dysbiosis of the endometrial microbiota and its association with inflammatory cytokines in endometrial cancer. Int. J. Cancer 2021, 148, 1708-1716. [CrossRef] [PubMed]

48. Miles, S.M.; Hardy, B.L.; Merrell, D. Investigation of the microbiota of the reproductive tract in women undergoing a total hysterectomy and bilateral salpingo-oopherectomy. Fertil. Steril. 2017, 107, 813-820.e1. [CrossRef]

49. Walsh, D.M.; Hokenstad, A.N.; Chen, J.; Sung, J.; Jenkins, G.D.; Chia, N.; Nelson, H.; Mariani, A.; Walther-Antonio, M.R.S. Postmenopause as a key factor in the composition of the Endometrial Cancer Microbiome (ECbiome). Sci. Rep. 2019, 9, 19213-19216. [CrossRef]

50. Walther-António, M.R.S.; Chen, J.; Multinu, F.; Hokenstad, A.; Distad, T.J.; Cheek, E.H.; Keeney, G.L.; Creedon, D.J.; Nelson, H.; Mariani, A.; et al. Potential contribution of the uterine microbiome in the development of endometrial cancer. Genome Med. 2016, 8, 1-15. [CrossRef]

51. Leoni, C.; Ceci, O.; Manzari, C.; Fosso, B.; Volpicella, M.; Ferrari, A.; Fiorella, P.; Pesole, G.; Cicinelli, E.; Ceci, L.R.; et al. Human Endometrial Microbiota at Term of Normal Pregnancies. Genes 2019, 10, 971. [CrossRef]

52. Fredricks, D.N.; Plantinga, A.; Srinivasan, S.; Oot, A.; Wiser, A.; Fiedler, T.L.; Proll, S.; Wu, M.C.; Marrazzo, J.M. Extra-vaginal Bacterial Colonization and Risk for Incident Bacterial Vaginosis in a Population of Women who Have Sex with Men. J. Infect. Dis. 2020, 10, 1093. [CrossRef]

53. Marrazzo, J.M.; Fiedler, T.L.; Srinivasan, S.; Thomas, K.K.; Liu, C.; Ko, D.; Xie, H.; Saracino, M.; Fredricks, D.N. Extravaginal Reservoirs of Vaginal Bacteria as Risk Factors for Incident Bacterial Vaginosis. J. Infect. Dis. 2012, 205, 1580-1588. [CrossRef]

54. Escalda, C.; Botelho, J.; Mendes, J.J.; Machado, V. Association of bacterial vaginosis with periodontitis in a cross-sectional American nationwide survey. Sci. Rep. 2021, 11, 1-9. [CrossRef]

55. Mändar, R.; Punab, M.; Borovkova, N.; Lapp, E.; Kiiker, R.; Korrovits, P.; Metspalu, A.; Krjutškov, K.; Nõlvak, H.; Preem, J.-K.; et al. Complementary seminovaginal microbiome in couples. Res. Microbiol. 2015, 166, 440-447. [CrossRef]

56. Vodstrcil, L.A.; Twin, J.; Garland, S.M.; Fairley, C.K.; Hocking, J.S.; Law, M.G.; Plummer, E.L.; Fethers, K.A.; Chow, E.P.F.; Tabrizi, S.N.; et al. The influence of sexual activity on the vaginal microbiota and Gardnerella vaginalis clade diversity in young women. PLoS ONE 2017, 12, e0171856. [CrossRef]

57. Agostinis, C.; Mangogna, A.; Bossi, F.; Ricci, G.; Kishore, U.; Bulla, R. Uterine Immunity and Microbiota: A Shifting Paradigm. Front. Immunol. 2019, 10, 2387. [CrossRef]

58. Bardos, J.; Fiorentino, D.; Longman, R.E.; Paidas, M. Immunological Role of the Maternal Uterine Microbiome in Pregnancy: Pregnancies Pathologies and Alterated Microbiota. Front. Immunol. 2020, 10, 2823. [CrossRef] [PubMed]

59. Liu, Y.; Wong, K.W.K.; Ko, E.Y.-L.; Chen, X.; Huang, J.; Tsui, S.K.-W.; Li, T.C.; Chim, S.S.-C. Systematic Comparison of Bacterial Colonization of Endometrial Tissue and Fluid Samples in Recurrent Miscarriage Patients: Implications for Future Endometrial Microbiome Studies. Clin. Chem. 2018, 64, 1743-1752. [CrossRef]

60. Zhou, B.; Sun, C.; Huang, J.; Xia, M.; Guo, E.; Li, N.; Lu, H.; Shan, W.; Wu, Y.; Li, Y.; et al. The biodiversity Composition of Microbiome in Ovarian Carcinoma Patients. Sci. Rep. 2019, 9, 1-11. [CrossRef] [PubMed]

61. Cancer Genome Atlas Research Network; Kandoth, C.; Schultz, N.; Cherniack, A.D.; Akbani, R.; Liu, Y.; Shen, H.; Robertson, A.G.; Pashtan, I.; Shen, R.; et al. Integrated genomic characterization of endometrial carcinoma. Nature 2013, 497, 67-73. [CrossRef]

62. Talhouk, A.; McConechy, M.K.; Leung, S.; Li-Chang, H.H.; Kwon, J.S.; Melnyk, N.; Yang, W.; Senz, J.; Boyd, N.F.; Karnezis, A.N.; et al. A clinically applicable molecular-based classification for endometrial cancers. Br. J. Cancer 2015, 113, 299-310. [CrossRef] [PubMed]

63. Roque, D.M.; Santin, A.D. Uterine cancer, mutational phenotype, and the era of immune checkpoint blockade. Expert Rev. Clin. Immunol. 2016, 13, 175-180. [CrossRef]

64. Versluis, M.A.C.; Marchal, S.; Plat, A.; De Bock, G.H.; Van Hall, T.; De Bruyn, M.; Hollema, H.; Nijman, H.W. The prognostic benefit of tumour-infiltrating Natural Killer cells in endometrial cancer is dependent on concurrent overexpression of Human Leucocyte Antigen-E in the tumour microenvironment. Eur. J. Cancer 2017, 86, 285-295. [CrossRef] 
65. Caselli, E.; Soffritti, I.; D’Accolti, M.; Piva, I.; Greco, P.; Bonaccorsi, G. Atopobium vaginae And Porphyromonas somerae Induce Proinflammatory Cytokines Expression In Endometrial Cells: A Possible Implication For Endometrial Cancer? Cancer Manag. Res. 2019, 11, 8571-8575. [CrossRef]

66. Gong, T.-T.; Wang, Y.-L.; Ma, X.-X. Age at menarche and endometrial cancer risk: A dose-response meta-analysis of prospective studies. Sci. Rep. 2015, 5, 14051. [CrossRef]

67. Cauci, S.; Driussi, S.; De Santo, D.; Penacchioni, P.; Iannicelli, T.; Lanzafame, P.; De Seta, F.; Quadrifoglio, F.; De Aloysio, D.; Guaschino, S. Prevalence of Bacterial Vaginosis and Vaginal Flora Changes in Peri- and Postmenopausal Women. J. Clin. Microbiol. 2002, 40, 2147-2152. [CrossRef]

68. Zhang, R.; Daroczy, K.; Xiao, B.; Yu, L.; Chen, R.; Liao, Q. Qualitative and semiquantitative analysis of Lactobacillus species in the vaginas of healthy fertile and postmenopausal Chinese women. J. Med Microbiol. 2012, 61, 729-739. [CrossRef] [PubMed]

69. Si, J.; You, H.J.; Yu, J.; Sung, J.; Ko, G. Prevotella as a Hub for Vaginal Microbiota under the Influence of Host Genetics and Their Association with Obesity. Cell Host Microbe 2017, 21, 97-105. [CrossRef]

70. Yang, T.-K.; Chung, C.-J.; Chung, S.-D.; Muo, C.-H.; Chang, C.-H.; Huang, C.-Y. Risk of Endometrial Cancer in Women With Pelvic Inflammatory Disease. Medicine 2015, 94, e1278. [CrossRef]

71. Fettweis, J.M.; Brooks, J.P.; Serrano, M.G.; Sheth, N.U.; Girerd, P.H.; Edwards, D.J.; Strauss, J.F.; Jefferson, K.K.; Buck, G.A.; The Vaginal Microbiome Consortium. Differences in vaginal microbiome in African American women versus women of European ancestry. Microbiology 2014, 160, 2272-2282. [CrossRef]

72. Laniewski, P.; Barnes, D.; Goulder, A.; Cui, H.; Roe, D.J.; Chase, D.M.; Herbst-Kralovetz, M.M. Linking cervicovaginal immune signatures, HPV and microbiota composition in cervical carcinogenesis in non-Hispanic and Hispanic women. Sci. Rep. 2018, 8, 1-13. [CrossRef]

73. Zhou, X.; Brown, C.J.; Abdo, Z.; Davis, C.C.; A Hansmann, M.; Joyce, P.; Foster, J.A.; Forney, L.J. Differences in the composition of vaginal microbial communities found in healthy Caucasian and black women. ISME J. 2007, 1, 121-133. [CrossRef] [PubMed]

74. Borgdorff, H.; Van Der Veer, C.; Van Houdt, R.; Alberts, C.J.; De Vries, H.J.; Bruisten, S.M.; Snijder, M.B.; Prins, M.; Geerlings, S.E.; Van Der Loeff, M.F.S.; et al. The association between ethnicity and vaginal microbiota composition in Amsterdam, The Netherlands. PLoS ONE 2017, 12, e0181135. [CrossRef] [PubMed]

75. Chatterjee, S.; Gupta, D.; Caputo, T.A.; Holcomb, K. Disparities in Gynecological Malignancies. Front. Oncol. 2016, 6, 36. [CrossRef]

76. Klymenko, Y.; Nephew, K.P. Epigenetic Crosstalk between the Tumor Microenvironment and Ovarian Cancer Cells: A Therapeutic Road Less Traveled. Cancers 2018, 10, 295. [CrossRef] [PubMed]

77. Siegel, R.; Ma, J.; Zou, Z.; Jemal, A. Cancer statistics, 2014. CA A Cancer J. Clin. 2014, 64, 9-29. [CrossRef] [PubMed]

78. Nené, N.R.; Reisel, D.; Leimbach, A.; Franchi, D.; Jones, A.; Evans, I.; Knapp, S.; Ryan, A.; Ghazali, S.; Timms, J.; et al. Association between the cervicovaginal microbiome, BRCA1 mutation status, and risk of ovarian cancer: A case-control study. Lancet Oncol. 2019, 20, 1171-1182. [CrossRef]

79. Banerjee, S.; Tian, T.; Wei, Z.; Shih, N.; Feldman, M.D.; Alwine, J.C.; Coukos, G.; Robertson, E.S. The ovarian cancer oncobiome. Oncotarget 2017, 8, 36225-36245. [CrossRef] [PubMed]

80. Miao, R.; Badger, T.C.; Groesch, K.; Diaz-Sylvester, P.L.; Wilson, T.; Ghareeb, A.; Martin, J.A.; Cregger, M.; Welge, M.; Bushell, C.; et al. Assessment of peritoneal microbial features and tumor marker levels as potential diagnostic tools for ovarian cancer. PLoS ONE 2020, 15, e0227707. [CrossRef]

81. Barrientos-Durán, A.; Fuentes-López, A.; De Salazar, A.; Plaza-Díaz, J.; García, F. Reviewing the Composition of Vaginal Microbiota: Inclusion of Nutrition and Probiotic Factors in the Maintenance of Eubiosis. Nutrients 2020, 12, 419. [CrossRef]

82. Nelson, T.M.; Borgogna, J.-L.; Michalek, R.D.; Roberts, D.; Rath, J.M.; Glover, E.D.; Ravel, J.; Shardell, M.D.; Yeoman, C.J.; Brotman, R.M. Cigarette smoking is associated with an altered vaginal tract metabolomic profile. Sci. Rep. 2018, 8, 1-13. [CrossRef]

83. Shen, J.; Song, N.; Williams, C.; Brown, C.J.; Yan, Z.; Xu, C.; Forney, L.J. Effects of low dose estrogen therapy on the vaginal microbiomes of women with atrophic vaginitis. Sci. Rep. 2016, 6, 24380. [CrossRef]

84. Vodstrcil, L.A.; Plummer, E.L.; Doyle, M.; Fairley, C.K.; McGuiness, C.; Bateson, D.; Hocking, J.S.; Law, M.G.; Petoumenos, K.; Donovan, B.; et al. Treating male partners of women with bacterial vaginosis (StepUp): A protocol for a randomised controlled trial to assess the clinical effectiveness of male partner treatment for reducing the risk of BV recurrence. BMC Infect. Dis. 2020, 20, 834. [CrossRef]

85. Bagnall, P.; Rizzolo, D. Bacterial vaginosis. J. Am. Acad. Physician Assist. 2017, 30, 15-21. [CrossRef]

86. Powell, A.; Ghanem, K.G.; Rogers, L.; Zinalabedini, A.; Brotman, R.M.; Zenilman, J.; Tuddenham, S. Clinicians' Use of Intravaginal Boric Acid Maintenance Therapy for Recurrent Vulvovaginal Candidiasis and Bacterial Vaginosis. Sex. Transm. Dis. 2019, 46, 810-812. [CrossRef]

87. Reichman, O.; Akins, R.; Sobel, J.D. Boric Acid Addition to Suppressive Antimicrobial Therapy for Recurrent Bacterial Vaginosis. Sex. Transm. Dis. 2009, 36, 732-734. [CrossRef] [PubMed]

88. Webb, L. Probiotics for preventing recurrent bacterial vaginosis. J. Am. Acad. Physician Assist. 2021, 34, 19-22. [CrossRef] [PubMed]

89. Marrazzo, J.M.; Dombrowski, J.C.; Wierzbicki, M.R.; Perlowski, C.; Pontius, A.; Dithmer, D.; Schwebke, J. Safety and Efficacy of a Novel Vaginal Anti-infective, TOL-463, in the Treatment of Bacterial Vaginosis and Vulvovaginal Candidiasis: A Randomized, Single-blind, Phase 2, Controlled Trial. Clin. Infect. Dis. 2018, 68, 803-809. [CrossRef] [PubMed] 
90. Bohbot, J.; Daraï, E.; Bretelle, F.; Brami, G.; Daniel, C.; Cardot, J. Erratum to: “Efficacy and safety of vaginally administered lyophilized Lactobacillus crispatus IP 174178 in the prevention of bacterial vaginosis recurrence" [J. Gynecol. Obstet. Hum. Reprod. 47 (2018) 81-7]. J. Gynecol. Obstet. Hum. Reprod. 2018, 47, 177. [CrossRef] [PubMed]

91. Russo, R.; Karadja, E.; De Seta, F. Evidence-based mixture containing Lactobacillus strains and lactoferrin to prevent recurrent bacterial vaginosis: A double blind, placebo controlled, randomised clinical trial. Benef. Microbes 2019, 10, 19-26. [CrossRef]

92. Cohen, C.R.; Parks, T.; Hemmerling, A. Randomized Trial of Lactin-V to Prevent Recurrence of Bacterial Vaginosis. N. Engl. J. Med. 2020, 383, 790-792. [CrossRef]

93. Lagenaur, L.A.; Hemmerling, A.; Chiu, C.; Miller, S.; Lee, P.P.; Cohen, C.R.; Parks, T.P. Connecting the dots: Translating the vaginal microbiome into a drug. J. Infect. Dis. 2020. [CrossRef]

94. Lev-Sagie, A.; Goldman-Wohl, D.; Cohen, Y.; Dori-Bachash, M.; Leshem, A.; Mor, U.; Strahilevitz, J.; Moses, A.E.; Shapiro, H.; Yagel, S.; et al. Vaginal microbiome transplantation in women with intracfigure bacterial vaginosis. Nat. Med. 2019, 25, 1500-1504. [CrossRef]

95. Tsakmaklis, A.; Vehreschild, M.; Farowski, F.; Trommer, M.; Kohler, C.; Herter, J.; Marnitz, S. Changes in the cervical microbiota of cervical cancer patients after primary radio-chemotherapy. Int. J. Gynecol. Cancer 2020, 30, 1326-1330. [CrossRef]

96. Tsementzi, D.; Pena-Gonzalez, A.; Bai, J.; Hu, Y.; Patel, P.; Shelton, J.; Dolan, M.; Arluck, J.; Khanna, N.; Conrad, L.; et al. Comparison of vaginal microbiota in gynecologic cancer patients pre- and post-radiation therapy and healthy women. Cancer Med. 2020, 9, 3714-3724. [CrossRef] [PubMed]

97. Chambers, L.M.; Kuznicki, M.; Yao, M.; Chichura, A.; Gruner, M.; Reizes, O.; DeBernardo, R.; Rose, P.G.; Michener, C.; Vargas, R. Impact of antibiotic treatment during platinum chemotherapy on survival and recurrence in women with advanced epithelial ovarian cancer. Gynecol. Oncol. 2020, 159, 699-705. [CrossRef]

98. Chambers, L.M.; Michener, C.M.; Rose, P.G.; Reizes, O.; Yao, M.; Vargas, R. Impact of antibiotic treatment on immunotherapy response in women with recurrent gynecologic cancer. Gynecol. Oncol. 2021, 161, 211-220. [CrossRef] [PubMed]

99. Routy, B.; Le Chatelier, E.; DeRosa, L.; Duong, C.P.M.; Alou, M.T.; Daillère, R.; Fluckiger, A.; Messaoudene, M.; Rauber, C.; Roberti, M.P.; et al. Gut microbiome influences efficacy of PD-1-based immunotherapy against epithelial tumors. Science 2018, 359, 91-97. [CrossRef] [PubMed]

100. Davar, D.; Dzutsev, A.K.; McCulloch, J.A.; Rodrigues, R.R.; Chauvin, J.-M.; Morrison, R.M.; Deblasio, R.N.; Menna, C.; Ding, Q.; Pagliano, O.; et al. Fecal microbiota transplant overcomes resistance to anti-PD-1 therapy in melanoma patients. Science 2021, 371, 595-602. [CrossRef] 